\title{
LUT
}

University

\section{Human resources - strength and weakness in protection of intellectual capital}

Olander Heidi, Hurmelinna-Laukkanen Pia, Heilmann Pia

This is a Final draft

version of a publication

published by Emerald Group Publishing

in Journal of Intellectual Capital

DOI: $10.1108 / \mathrm{JIC}-03-2015-0027$

Copyright of the original publication: ( Emerald Group Publishing

Please cite the publication as follows:

Olander, H., Hurmelinna-Laukkanen, P., Heilmann, P. (2015). Human resources - strength and weakness in protection of intellectual capital. Journal of Intellectual Capital, vol. 16, issue 4. pp. 742-762. DOI: 10.1108/JIC-03-2015-0027

This is a parallel published version of an original publication. This version can differ from the original published article. 


\title{
Human resources - Strength and weakness in protection of intellectual capital
}

\author{
Heidi Olander \\ LUT School of Business and Management, \\ Lappeenranta University of Technology, Lappeenranta, Finland \\ Pia Hurmelinna-Laukkanen \\ Oulu Business School, University of Oulu, Oulu, Finland, and \\ Pia Heilmann \\ LUT School of Business and Management, \\ Lappeenranta University of Technology, Lappeenranta, Finland
}

\begin{abstract}
Purpose: Human resources in knowledge intensive industries create the basis for continuing innovation and subsequent firm performance. At the same time, they pose risks for the competitiveness of the firm: Unwanted leaking of knowledge and intellectual capital to outsiders exposes firm-critical knowledge, and knowledge leaving with a departing key employee may jeopardise the firm's projects. We empirically examine how human resource management can serve as a protection mechanism to diminish knowledge leaking and leaving via employees.
\end{abstract}

Methodology: We approach these issues through a case study utilising interview data from 22 interviews within two large R\&D intensive firms.

Findings: Human resources could be seen both as a strength and weakness of a firm with respect to knowledge protection. The findings indicate that there are numerous formal and softer practices related to commitment, trust, motivation, and sense of responsibility available to deploy to strengthen loyalty and to improve preservation of intellectual capital.

Originality: While HRM aspects have been widely discussed with regard job profitability and efficiency in generating intellectual capital, their connection to knowledge protection has often been overlooked. This study aims to contribute to this area. 
Keywords: HRM; knowledge protection; knowledge leaving; knowledge leaking; commitment; loyalty; motivation, trust; consciousness; sense of responsibility

\section{Introduction}

Human resources are invaluable sources of innovation and competitive advantage for firms (Sels et al., 2006; Massingham and Tam, 2015). Insightful, experienced and enthusiastic research and development (R\&D) personnel can produce new ideas themselves and/or in collaboration with partners outside the company (Riahi-Belkaoui, 2003). However, human resources are one of the most volatile resources (e.g. Harcourt and Wood, 2007), and relatively little is known about how they can be managed to sustain competitiveness. While employees of the firm engage in knowledge sharing, they also deal with the highly-confidential, innovation-related knowledge that should not leak beyond the firm boundaries; it has been noted that any resource can only be valuable as long as it is unique and distinct to the company (Barney, 1991). Besides knowledge leakages induced by employees, key employees leaving may pose risks for the firm's innovation activities. One of the central options available to management to forestall knowledge leaking and leaving is relying on human resources management (HRM) -related mechanisms, which can help retain employees in the firm as a productive resource, and foster their willingness to create, share, and still simultaneously (the focal issue in this study) protect intellectual capital consistently (see Ahuja et al., 2013, HurmelinnaLaukkanen and Puumalainen, 2007). Accordingly, it is important for innovation managers to understand and manage human resources from this point of view.

Earlier research on protecting a firm's intellectual assets has concentrated to a large extent on the use of formal mechanisms of protection and appropriation such as contracts and patents (Cohen et al., 2000; Davis, 2004; Hertzfeld et al., 2006; Lang, 2001). At the same time informal mechanisms have not attracted as much research interest - despite the recognition that formal means cannot cover everything. The available HR-related mechanisms for knowledge protection in innovation management, in particular, have so far garnered rather limited attention. Some research exists on 
employment contracts and non-disclosure agreements, but these are closely related to the formal forms of protection. While some researchers (e.g. Hurmelinna-Laukkanen and Gomes, 2012; Hurmelinna-Laukkanen and Puumalainen, 2007; Baughn et al., 1997; Liebeskind, 1996; 1997) have brought up the issue of using HR-related practices for knowledge protection in innovation management, the findings have been somewhat inconclusive. Some of the research findings highlight the importance of these mechanisms, while some suggest that they might not provide very strong protection.

Kinnie and Swart (2012) note how HR practices play a strategic role in managing the way in which employees relate to both to the profession and the firm. In line with this, HR practices influence employees' attitudes towards knowledge protection; if they see that as something that makes their work more difficult (see Hannah, 2005; Hannah and Robertson, 2014) or as a natural part of innovation management. These attitudes may affect the company's opportunities for the appropriation of knowledge and intellectual capital, both in terms of profiting from innovations, and the possibilities of generating further innovation from intellectual capital (Ahuja et al. 2013).

While it is widely recognised that much of the knowledge and intellectual capital that creates a competitive advantage is embodied within the firm's employees, there the ways in which knowledge management and human resources management could help preserve competitive advantage warrant more research (Currie and Kerrin, 2003; Haesli and Boxall, 2005; Storey and Quintas, 2001; CameloOrdaz et al. 2011). For example, protection aspect of managing intellectual capital has been touched in earlier research (e.g., Kianto et al., 2010), but there has thus far been very little in-depth, nonsurvey-based empirical work on linking intellectual capital and knowledge management with HRM (exceptions include Currie and Kerrin, 2003; Haesli and Boxall, 2005). In particular, informal mechanisms have been studied mostly in the context of SMEs (e.g. Leiponen and Byma, 2009; Olander et al., 2009; 2011), and in many cases, their focus has been more on securing knowledge sharing than knowledge protection (Currie and Kerrin, 2003; Haesli and Boxall, 2005). 
Likewise, there are some studies addressing the practice of hiring competitors' employees to enhance a firm's knowledge base, but practices to diminish the outbound knowledge flows (e.g., competitors hiring away the focal firm's employees) are much less studied (Agarwal et al. 2009). Consequently, little is known about the extent to which larger companies rely on HR-related protection mechanisms and what they could do to optimise their effect. For example, a quantitative study by HurmelinnaLaukkanen and Puumalainen (2007) among large firms suggested that although HRM should matter as a protection mechanism, it might not be seen as a valuable source of protection in large firms. More understanding is needed on how HR-related knowledge protection can mitigate employee-related risks simultaneously acknowledging the importance of intentional and needed knowledge flows.

Based on the identified research gaps, the authors present a research question: How, and through which factors, can human resource management practices improve the ability of companies to limit knowledge leaking and leaving?

This research question is addressed by examining literature related to knowledge and innovation management as well as that related to knowledge protection, strategic management, and HRM. For empirical evidence, qualitative interview data from R\&D units of two large Finnish high technology manufacturing firms is used. The authors have organized the paper by reflecting both the data obtained and theory hand in hand to identify central aspects related to knowledge protection, and provide insights that will be of use to managers in large firms. Discussion and conclusions sections summarise these insights and offer avenues for future research.

\section{Protecting tacit knowledge within companies}

A great deal of research has concentrated on how to protect firms' intellectual capital and assets (e.g., Teece, 1986; James et al., 2013; Ahuja et al. 2013; Cohen et al., 2000; Davis, 2004; Hannah, 2005; Hertzfeld et al., 2006; Klein Woolthuis et al., 2005; Liebeskind, 1996; Harabi, 1995; HurmelinnaLaukkanen and Puumalainen, 2007; Agarwal et al. 2009; Aaron and Finkin, 1998). In these studies, it 
has been acknowledged that knowledge is a company's strategic asset (Nonaka et al., 2000) and can be roughly split into the explicit and tacit. The most valuable intellectual capital of a company often lies in the knowledge reserves of its employees (Ståhle and Grönroos, 1999; Bontis and Fitz-Enz, 2002), in a mostly tacit form. Tacit knowledge is hard to codify and transfer and is not easily visible (Nonaka and Takeuchi, 1995; Zander and Kogut, 1995). Tacitness of knowledge therefore characteristically offers protection for company-critical intellectual capital. However, this may also create problems in terms of adequate intra- (and inter-)firm knowledge exchange and innovation activity.

Moreover, losing tacit knowledge through knowledge leaving the firm with staff is a severe problem not only because of the risk of imitation, but also due to resulting disruptions in firm activities. Tacit knowledge can walk out of one company and in to another one with the transfer of key employees with critical skills (Boxall, 1998; Liebeskind 1997). Certainly, the complexity of most innovations, for example, means one employee hardly ever possesses all the relevant knowledge alone (McEvily and Chakravarthy, 2002; Liebeskind, 1996; 1997), but relevant pieces of knowledge can still be at risk. On the other hand, if knowledge is put into codified form, the protection provided by complexity, unobservability, and other similar features of tacit knowledge are lost, and the need to find efficient forms for securing appropriation possibilities is induced.

Because of the very reason that valuable intellectual capital often resides with employees, the options available to a company to protect (tacit) knowledge also depend quite heavily on its employees' ability and willingness to act as gatekeepers. In present day labour markets, the employees change jobs quite frequently. This is partly due to the competitive situation in many industries, and geographic centralisation and urbanisation giving employees more choice (Chesbrough, 2003). On the other hand, economic pressure is driving reductions in the workforce in many sectors. This transition seems to be the trend in all of the industrialised countries. An employee departing a firm - no matter what the reason is - always means losing some (tacit) knowledge. Particularly in knowledge intensive industries, the consequences can be critical (Droeger and Hoobler, 2003). Enhancing employees' 
understanding of knowledge protection and fostering their willingness to prevent intellectual capital from leaking and from leaving the firm could improve the level of appropriation and firm performance. How this can be achieved, is therefore a central issue for any firm's managers.

\section{Cross-industry qualitative study on HRM-related protection}

\section{Method and analysis}

Given the research questions, and the lack of existing knowledge, an exploratory, qualitative research approach was considered to be appropriate. Search for the answers was therefore started with the examination of the R\&D units of two high-tech Finnish manufacturing companies. The case companies were from the engineering ('Engineering Company') and IT industries ('IT Company'). Following the reasoning of the ideal environment for exploring strategies related to intellectual capital and knowledge management and HRM (Haesli and Boxall, 2005), the companies were selected based on their involvement in $R \& D$, their roles as major employers of $R \& D$ engineers, the existing evidence of engagement in competition with other organisations for talented R\&D engineers, and, on a more practical level, their willingness to grant permission to collect data at different levels of the organisation. The two industries are quite different, for example, with respect to the speed of technological change they deal with, the first having relatively long product life cycles with incremental innovation, and the second working in a fast changing industry with continuous radical and incremental innovation with short product life cycles and an environment known for its fierce competition. These differences improve the generalizability of the findings to different types of high technology manufacturing firms.

The authors conducted 22 individual interviews in total - 12 in Engineering Company and 10 in IT Company. The authors applied a multi-level research setting where interviewees were selected from all the four levels within the R\&D units: strategy, expert (HR-managers, R\&D managers, legal experts), superiors, and operative level R\&D employees (engineers and researchers working at an 
inter-firm collaboration interface) (see Table 1 below). This allowed investigating the views of both managers and employees (Haesli and Boxall, 2005). The interviews lasted approximately 90 minutes each. They were recorded with the permission of the interviewee and transcribed for analysis. A semistructured theme interview form was used covering issues related to the role of HR-related practices in knowledge protection. The topics examined in earlier research on human resource management cover a wide range of different aspects ${ }^{1}$, but the authors did not make any pre-selection on those and avoided describing them during interviews. This allowed the interviewees to describe knowledge protection related issues quite freely, yet enabled keeping the focus, and making further in-depth questions during the interviews.

Table 1 Case companies and number of interviewees per level

\begin{tabular}{llllll}
\hline Company $(A \& B)$ & $\begin{array}{l}\text { Strategy } \\
\text { (\# employees }\end{array}$ & Manager & Superior & Operative & Total \\
& interviewed) & & & \\
& & 4 & 2 & 4 & 12 \\
\hline (A) Engineering & 2 & 2 & 2 & 4 & 10 \\
(B) IT & 2 & 6 & 4 & 8 & 22 \\
\hline Total & 4 & & & & \\
\hline
\end{tabular}

${ }^{1}$ Topics include organization design, workforce planning, recruitment, selection, placement, staff retention, commitment, loyalty, contract ending, employee engagement, performance management, leadership, managing attendance and absence, change and development, performance management, knowledge management, career management, motivation, compensation, benefits and services, organizational/employee learning, information sharing, equality, diversity management, discipline, rewards, talent management, ethics, labour relations, corporate social responsibility, IT in HR, health and well-being, work-life balance, downsizing, flexibility, communication, and global HRM (Dessler, 2008; Redman and Wilkinson, 2009; Torrington et al., 2011; Truss et al., 2012;).

${ }^{1}$ We refer to the source in plural when we cite the similar ideas of two or more interviewees from the same level. 
The analysis was conducted on 262 pages of interview transcripts using abductive logic. The first round of analysis established a coding frame based on the protection/appropriation-related themes arising from the theory. These themes included the level of the firm's dependency on its employees, the perceived significance of the loss of tacit knowledge when employees left, the loss of intellectual capital through unwanted knowledge leaks, and the retention of knowledge. The data were then content-analysed in order to identify common elements for each of these categories, to capture the dominant elements, and to build a story based on them. In the second analysis round, a comparative case study approach was adopted (Eisenhardt and Graebner, 2007). The different industries and the perceptions of employees across different levels within the companies were considered. In both rounds of analysis, research triangulation was applied, as two researchers participated in the coding phase and contributed to the key findings individually. The findings were then discussed jointly to enhance consistency testing between researchers. In the following, the themes that emerged in the empirical data are introduced and reflected to theoretical discourse.

\section{Role of tacit knowledge and personnel-dependence on key individuals and use of isolating appropriability mechanisms}

\section{Empirical findings}

Tacit knowledge held by employees could be expected to constitute a key asset for the case firms' innovativeness, and therefore, we started our examination by establishing how relevant such assets were perceived to be in the case firms. In both companies, human resources were considered critical to innovativeness and competitiveness. Across all organisational levels in both companies, the interviewees emphasised the role of professional knowledge and expertise residing in the employees.

We have an organisation of professional software developers, it is the type of organisation that always depends on what people know, and we have different skills and competence areas, which means that the role of individual employees is accentuated. (R\&D employee, Engineering Company) 
Of course, you can store knowledge in systems, but to be able to use that documentation meaningfully, you need people and their brains. The potential to apply knowledge and solve problems can only reside in people. (Manager, Engineering Company)

-This is a knowledge intensive business and it means our core knowledge is in our personnel. -It is accentuated in the early stages, when you only have a fuzzy idea, or belief this is truly important, it all derives from the individual. But in the later phases, some of that core knowledge already resides in technology and processes as well. (Managers², IT Company)

It is worth noting that in these knowledge intensive companies, the interviewees did not mention employees leaving to go and work for a rival as posing any greater risk than leaving in general, which suggests that leaving is seen as causing primarily internal issues, rather than direct competitor and competition-related problems.

Nevertheless, the case firms applied various mechanisms to safeguard the potential residing in their human resources. In terms of formal mechanisms (e.g. Hertzfeld et al., 2006), permanent employment contracts were utilized, and non-disclosure agreements (NDAs) were commonplace at all levels. While permanent (or strictly-speaking, ongoing) employment contracts may be a sign of the company's commitment to the employee and NDAs provide a formal reminder of responsibilities related to confidential knowledge, these were considered inadequate by several managers to mitigate leaking and leaving related knowledge risks.

Engineering Company had made continuous efforts to reduce its dependence on individuals (and thereby, to limit the risk related to knowledge leaving) by careful documentation. This was especially clear in the strategy level interviews. In IT Company, documentation was also considered an important - although not completely unproblematic - means to prevent intellectual capital from leaving. Also IT Company seemed to be in favour of more informal ways of countering the risks. 
We can only hope we've done a good job in documenting everything in advance, in case a key employee leaves. (Strategy manager, IT Company)

When someone leaves, we have them focusing on documentation for the last weeks of employment. (R\&D employee, IT Company)

However, the operative level employees of Engineering Company felt that the expertise of the employees could not easily be captured, and suggested that sustaining competitiveness was more about keeping the people, and keeping them committed and motivated.

\section{Reflection to theory}

Reflecting these findings against earlier theoretical discourse illustrates some important aspects. Labour legislation and the use of HRM for enhanced appropriability are quite distinct ways to protect tacit knowledge. For example, the law may provide an employer with a right to task employees to take part in IPR training, but it cannot determine whether the employees are willing to learn, or to apply the learning to improve the appropriability of innovation and knowledge. On the other hand, HRM can be utilised to improve these aspects.

Another central point is that while there are a range of HRM issues and practices used in organisations (see endnotes), from the point of view of knowledge protection, those means that increase loyalty and the skills of staff both in terms of reducing knowledge leakages and knowledge leaving the firm, can be considered the most relevant ones (see Liebeskind, 1997). The role of loyalty-enhancing practices is emphasised, and will be in the future, because of the competition for a competent workforce. It is important to succeed not only in recruiting but also in retaining current personnel (Heilmann, 2010; Haesli and Boxall, 2005). In this respect, issues such as employee commitment and motivation (highlighted in the case firms also) are important. 


\section{Enhancing loyalty - commitment-based knowledge protection and psychological contracts}

\section{Empirical findings}

Returning to our empirical evidence, although the firms operated under different market conditions, increasing short-term thinking was a shared concern of the R\&D employees. The changes in the competitive environment were seen to have resulted in a management-by-quarter approach and fewer options for long-term development and technological advance, which remained a key target for R\&D employees. However, the interviews revealed that the employees felt quite enthusiastic about their work and were willing to give their best input to the company. Even with IT Company facing considerable challenges with its competitive environment and the subsequent need to let people go in the past, its employees seemed to be quite committed.

For me, this entire commitment thing is that we are working in a Finnish company, with good managers, and with an opportunity to have a job for years. (R\&D employee, Engineering Company)

We have people who share this thing, interest in advances in technology and willing to do certain type of work to advance it further. This is why we may openly and informally discuss issues with each other [internally], not based on formal roles. I think it is the best way to make people committed. (R\&D employee, IT Company)

I also have to say that this workplace is quite unique, our people could not find similar jobs elsewhere. (R\&D employee, IT Company)

Furthermore, the data suggests that both case firms made efforts to retain employees and to increase their willingness to look after the firm's intellectual assets. They had used a variety of rewards and tailored career paths with varying tasks according to length of service with the company and accumulated capabilities to enhance commitment. For example, in Engineering Company career path planning had been adopted only recently, but there had been rapid advances in the development of the 
concept. Although not all positions offered opportunities for promotion, overall, the company was seen as offering good opportunities for learning and professional development. The same applied to IT Company.

Respondents at all levels of the organisation also acknowledged the role of intangible rewards in increasing commitment. Even if there were tangible reward systems applied, they were considered to be either poorly aligned with the content of work (IT Company) or favouring top management instead of operational-level staff (Engineering Company). This was seen as eroding the positive atmosphere. Although not particularly rating bonuses or other concrete rewards, many interviewees noted the benefit of giving positive feedback and appraisal for good work (e.g. with regard to handling confidential knowledge assets). Yet as the comments below demonstrate, there was concern over openness in giving feedback. It was also not systematic but more dependent on the personality of managers and supervisors, which was seen as a problem.

We should have more means to give intangible rewards to our employees. (Manager, Engineering Company)

-I think it's a part of our culture; we do not usually thank employees in public.

-We only give modest thanks... (Supervisors, Engineering Company)

It depends very much on the person you are dealing with; people are quite different in the way they give feedback. (R\&D employee, IT Company)

Nevertheless, in terms of enhancing commitment, getting feedback on a job well done was considered very important at the operative level in both companies: 
Feedback has a quite a lot of effect on internal motivation, of course it is nicer to get some positive than negative feedback but the most essential thing is, it is based on honesty and realism. (R\&D employee, Engineering Company)

- Definitely it feels good to hear that you have done things right.

- For instance, successful projects have been highlighted in shared events and people are given recognition. (R\&D employees, IT Company)

Finally, as one interviewee stated, there is a mutual moral collaboration agreement between employees and superiors, and ethical standards were followed. A manager violating the moral collaboration agreement might lead to employees becoming frustrated, perhaps even to the extent where they deliberately leak knowledge.

\section{Reflection to theory}

Commitment to an organisation and its goals, and an intention to stay with the organisation, are seen as desirable outcomes promoting positive organisational citizenship behaviour, reduced turnover, increased productivity and job satisfaction (Mir et al., 2002). Theoretical discourse has approached commitment as an attachment to an organisation characterised by shared values and a strong belief in the organisation's goals, a desire to remain in the organisation, and a willingness to expend effort on its behalf (Fiorito et al. 2007; Mowday et al., 1979; 1982). The last characteristics are especially relevant to knowledge protection - former addressing the risks of knowledge leaving and the latter affecting knowledge leaking. These aspects were present in the case firms.

The above described situation at the case firms suggests, first, that different types of organisational commitment are present. Most theorists agree that organisational commitment can be seen in terms of different dimensions: affective (representing a person's emotional attachment to the organisation), calculative, continuance (which refers to transactional costs when leaving the organisation) or normative commitment (a person's obligation to the employer) (see e.g. Mowday et al. 1979; 
Reichers, 1985; Allen and Meyer, 1990; Meyer et al. 1993). Personal commitment to the organisation comprises these components, which are valued differently by different people.

References to normative commitment, for example, suggest that labour legislation (and its terms supporting knowledge protection) can become connected to the creation of commitment. While not highlighted too much in the case firms, the employment contracts form the basis for relationships. Affective commitment, on the other hand, is an attitudinal phenomenon related to personality traits and job-related factors, and it is connected to the willingness of an employee to support organisational goals, including those related to safeguarding and supporting appropriation through careful handling of firm-specific intellectual capital (Camelo-Ordaz et al., 2011). This type of commitment seemed to be particularly prevalent in the case firms: The interviewed managers reported that they were looking for affective commitment rather than the calculative commitment that does not create long-term commitment towards the company. Calculative or continuance commitment is the result of employees perceiving that organisational membership will serve their self-interest, and results in individuals staying with their employers - which, in turn, improves the chances of mitigating risks related to knowledge leaving. However, even if calculative commitment were present in the case firms, it is not the most sought after type of commitment because it engenders other possible weaknesses such as reduced efficiency.

Beyond these types of commitment, the second aspect emerging from the data is that different means could be promoted to increase commitment for knowledge protection. Allen and Mayer (1997) state the factors that affect the commitment of a person are personal characteristics, working experience (e.g. fulfilment of expectations, reward system, career progression possibilities, personal relations in the organisation, personal ranking in the organisation), work role (wide and challenging tasks, interest, autonomy, significance, responsibility and power in the organisation, clarity of work role) and organisational structure (the organisation's age, managerial traditions, size and control system). This seems to be the case in the examined organizations where such aspects came up. Therefore, it can be argued that a wide range of HRM practices (and not just norms of labour legislation, for 
example) are relevant to knowledge sharing and protection (see also Hurmelinna-Laukkanen and Gomes, 2012).

The empirical evidence suggests also, that, like indicated in theoretical discussions, commitment is tightly connected to the psychological contract between the employer and the employee (Argyris, 1960; Rousseau and Wade-Benzoni, 1995; Schalk and Rousseau, 2001; Rousseau, 1995). The concept of the psychological contract can be defined as an exchange agreement of promises and contributions between two parties, an employee and an employer (Janssens et al., 2003). It is the invisible glue binding individuals to the organisation over time, thereby affecting knowledge leaving and leaking tendencies. The individual's objective, external career consists of the positions held in the organisation, but the subjective internal career is the process of psychological contracting (Herriot, 1992). Psychological contract theory also represents the employment relationship in terms of the subjective beliefs of employees and their employers of a promise being made (Rousseau and Schalk, 2000; Rousseau, 2011). The theory refers to the implicit, reciprocal rights and obligations that individuals perceive within exchange relations (Rousseau, 1995; 2011) - an aspect that was also visible in the case firms and that directly connects to HR-related protection of intellectual capital. However, there is also another side to this: A connected, yet distinctive factor that is present is trust.

\section{Trust}

\section{Empirical findings}

As suggested above, both firms were seen as trusted employers with a long tradition, resulting in a shared positive image among their employees - particularly among personnel with the longest service. Trust was seen to be part of realising knowledge protection, but the sensitivity of trust building was acknowledged by the superiors: In some cases trust and referring to protection needs could be seen as substitutes. 
Even if I wouldn't have shared that knowledge in the first place myself, I will not criticise employees who have. It will destroy their self-confidence, and then they'll confirm every single thing with you after that. (Superior, IT Company)

In order to avoid the situations described in the preceding quote, superiors seem to educate the employees to quite an extent, but informally rather than in terms of having employees take part in formal training so as to retain trusting relationships. The informality of education on confidentiality issues is part of the trusting culture, and helps develop reciprocal relationships. The approach is likely to encourage the employees to trust that the practices in place are there for a valid reason. It seems that the superiors and longer-tenured peers serve an important role in this process as role models for knowledge sharing and protection:

We discuss the limits of knowledge sharing a lot, especially with the new employees. When it comes down to it, we have some smart employees. They will learn from what their more experienced peers do and how they behave in collaboration situations. (Superior, IT Company)

In fact, the practices that were identified to be related to trust building (and that were also in line with the loyalty building and knowledge protection needs) were open communication and equal treatment of employees. The R\&D employees and their superiors thought that trust was particularly visible in the close collaboration between the two groups. Communication was found to be good, and the R\&D employees mentioned that their opinions were taken into account. Employees also felt they were trusted, as their work was not constantly monitored.

I feel that we are trusted [by our superiors]. It can be seen in how our superiors listen to us before acting. They let us have a say on what we think is the smart thing to do. (R\&D Employee, Engineering Company) 
We are trusted. Superiors don't need to see us every day to know that we are still doing our job well.

The employees' trust with superiors is better than with managers, as we don't communicate with them as much. (R\&D Employee, IT Company)

The operative employees in IT Company were more reserved when talking about trust issues than the employees at the management-level of the company, which could of course have something to do with the personnel dismissals in the recent past. In fact, some R\&D employees admitted that they felt these events had had a negative effect on the trust in the management. Yet, they wanted to act appropriately in terms of protecting the company confidential knowledge.

\section{Reflection to theory}

Indeed, theory suggests that long-term relationships base on trust and mutual respect, and that also reflects to loyalty - and, subsequently, knowledge risks. Employees offer loyalty, conformity to requirements, and consideration of their employer's goals, and trust that their employer will not abuse their goodwill (e.g., by mistreating valuable intellectual capital). In return, the organisation is supposed to offer security of employment, promotion prospects, training and development and some flexibility on the demands made for employees if they are in difficulty. Predictability with regard to these issues is relevant for trust development (cf. Brattström et al., 2012).

However, global competition, new technology, downsizing, and delayering among other things have made this more challenging. Many employers no longer keep their side of the bargain. Instead of a contract being based on a long-term relationship, it is far more likely to be a short-term transactional, economic exchange (Arnold, 1997). Lawler (2003) argues that employees moving more frequently and global competition are undermining the very concept of loyalty in the organisational context. Knowledge is withheld and used in a calculated way more easily. In addition, employment relationship termination programmes prompted by the increasingly competitive situation and global financial crises may signal to employees that it may not be wise to trust and fully commit to any one 
company (e.g., Harcourt and Wood, 2007; Eger, 2004). In this situation however, it is more important than ever to make sure that innovation-related knowledge is protected through attracting new talent to learn early enough from the existing experts, and holding on to the key talent in house by making substantial efforts to promote trust among employees (Brattström et al., 2012) and to create a high level of motivation (Sels et al., 2006). The more accountable and trustworthy managers are perceived to be, the more effective are motivational practices in promoting positive attitudes towards the organisation (Innocenti et al., 2011), and the less likely the employees are approaching intellectual assets individualistically and opportunistically.

\section{Motivation}

\section{Empirical findings}

The trusting relationships within the case firms also allowed the firms to provide motivating tasks for their employees. This too affected loyalty towards the firm, and protection of core intellectual capital.

In addition to the above-mentioned recognition for achievement and its effects on commitment, the companies were also using the practices of advancement and granting more responsibility. In a business unit with researchers interested in special professional domains, challenging and motivating tasks in their specific fields were found to be important to maintain the employees' levels of motivation and contentment with their work. It was also a question of empowerment: people were allowed more freedom in completing tasks and organising their work.

The important thing is that we have meaningful tasks that are of interest to our employees. (Manager, Engineering Company)

We need to give our people jobs and tasks to inspire them, based on their areas of expertise. (Manager, IT Company) 
Although the above-mentioned career paths and opportunities to be promoted were present in both companies, they were not significant sources of motivation. Many interviewees described how the desire to achieve and create the new pushes them forward as professionals. At an operational level, the following notion exemplifies well the internal motivation that many employees seem to possess:

Even if there were no means to reward people, we might still work as much as we do now, because we want to innovate and create the new. (R\&D employee, Engineering Company)

This kind of internal motivation, together with affective commitment to the company, creates a rather stable situation in both companies, easing the issues with knowledge risks.

\section{Reflection to theory}

The purpose of motivational theories is in general to predict behaviour. Motivation can be explored from three distinct but related perspectives: goals (the main motives for certain behaviour), decisions (why certain goals are pursued), and influence (how an individual can be motivated to do something) (Huczynski and Buchanan, 2007). Motivation is multifaceted as it concerns action and the internal and external forces that influence a person's choice of action (Mullins and Christy, 2013).

Maslow's theory of nine innate needs or motives focuses on goals (1954), and the expectancy theory of (work) motivation (Huczynski and Buchanan, 2007; Vroom, 1964) augments it by addressing individual differences in motivation and behaviour. According to expectancy theory, behaviour results from a conscious decision-making process based on expectations, measured as the assessed subjective probability that an individual has about the results of different behaviours leading to performance and to rewards. Therefore, motivation can improve obedience to knowledge protection guidelines (Hannah and Roberson, 2014).

Furthermore, Herzberg's motivation-hygiene theory (or two-factor theory or satisfier-dissatisfier theory) (Herzberg, 1974) has points of overlap with the knowledge protection notion. The two 
'factors' in this theory refer to sets of hygiene factors (company policy and administration, level and quality of employee supervision, quality of interpersonal relations, working conditions, salary and other forms of remuneration, status, and job security), and motivation factors, or 'motivators' (personal achievement, recognition of achievement, the work itself, responsibility given to an individual, advancement of one's career, and personal growth and development). If the hygiene factors are not satisfied, employees will be dissatisfied and unmotivated. If only the hygiene factors are satisfied, personnel will not be dissatisfied, but will not be motivated either. If both hygiene and motivation factors are satisfied, employees are also motivated. For example, building more responsibility into the individual's work (e.g. for holding confidential information) is a motivator that makes the employee more satisfied. Further motivation can be derived from providing option arrangements, for example (Hurmelinna-Laukkanen and Puumalainen, 2007, Ahuja et al., 2013). It seems that in the case firms, both conditions were met. It follows that the degree of motivation can reflect the level of loyalty towards the organisation and that conclusion is the most relevant to knowledge protection. Motivation can materialise in different aspects, starting from the willingness to stay within the firm, which is directly linked to knowledge leaving types of risks.

\section{Conscientiousness, and sense of responsibility}

\section{Empirical findings}

In addition to above discussed aspects, the analysis of the data exposed a specific factor that could be highly relevant for protection and appropriation of intellectual capital. In both companies, the informants from the managerial level identified a 'common sense of justice' as a typical cultural characteristic in Finland, resulting in a shared assumption that people feel a sense of responsibility towards their employer and do not aim to harm its business. This had a notable effect on knowledge protection aspects, especially with regard to knowledge leaking issues.

Our values here are based on the assumption that you take care of the confidentiality issues, particularly with external stakeholders, and it is taken seriously. (Manager, Engineering Company) 
- If you wanted to leak knowledge, of course you could do that. But protection is based on trust and employee willingness to follow that norm.

- It starts with our employees realising the importance of protecting knowledge, and acting morally and ethically as company representatives. (Managers, IT Company)

In addition to the general sense of justice and responsibility, employees demonstrated a sense of responsibility towards the company based on their experience of its practices. Current staff assumed that even their former colleagues who had left the company would follow the expected standards of responsibility. This could be one reason why events where employees left and were hired by competitors did not raise notable concerns. However, as one interviewee pointed out, in knowledge intensive business it may be challenging to draw a line between general professional skills that can be freely utilised after employment, and business-critical intellectual capital to be protected. Again, the employees' own judgement and acting according to the general moral standards was underlined by managers of both companies.

\section{Reflection to theory}

The sense of responsibility, as described by the interviewees seems to be a construct that is related to loyalty and conscientiousness (Matzler et al., 2011), for example, but is also distinct from them. Going back to the literature, the sense of responsibility emerges in different settings, such as crossfunctional teams (McDonough, 2000), and knowledge management (Oltra, 2005), and is associated with commitment. According to John and Srivastava (1999, p. 121) "Conscientiousness describes socially prescribed impulse control that facilitates task- and goal-behaviour, such as thinking before acting, delaying gratification, following norms and rules, and planning, organising, and prioritising tasks". Conscientiousness refers to employees being dependable and responsible, and doing more than is asked of them (Matzler et al., 2011). This suggests they might also be more motivated to safeguard their firm's interests with regard to protecting knowledge. 


\section{Conclusions}

\section{Summary of the findings}

Human resources could be seen both as a strength and weakness of a firm with respect to protection of intellectual capital. Employees are valuable receptors, creators, and gatekeepers of knowledge assets that a firm can use to generate valuable innovations. However, if human resources become the channel through which knowledge leaks from the organisation, severe problems emerge (HurmelinnaLaukkanen and Puumalainen, 2007; Mohamed et al. 2007; Norman, 2001). Therefore, identifying and implementing means that limit disruptions and imitation risks connected to knowledge leaving as well as unintentional and deliberate knowledge leaking are relevant - especially when there is a need to simultaneously avoid their excessively restrictive effect on much needed knowledge sharing (Chesbrough, 2003).

In line with the study by Olander et al. (2011) in the context of SMEs, we find that preserving the prerequisites for future innovation by keeping relevant intellectual capital within the case firms is of importance. For example, the employees of IT Company in our empirical study considered knowledge leaking to be a rather small chance and only a critical issue in the period close to product launches. It was also noted that such a risk could be diminished by restricting access to exclusive core knowledge. Both companies, however, confirmed they had a lot invested in the intellectual assets and talent of their key employees, and the departure of such an employee would create even greater problems.

With regard to the empirical evidence, a few specific notions can be made: The calculative type of commitment might have been expected from employees in IT Company due to the turbulent organisational environment, driving employees to adopt a more self-interested approach characterised by coping strategies to a challenging situation. Rather surprisingly, commitment seemed to be affective in nature (Mir et al., 2002; Allen and Meyer, 1990) and to be at relatively similar levels in both analysed companies. In challenging situations, where employees might be tempted to utilize - 
even abuse - the employer-specific intellectual capital and knowledge to promote their own position in job markets, the affective commitment seemed to act as an effective counterforce, and to improve knowledge protection conditions.

Furthermore, even if rapid change was seen to erode the positive environment and opportunities for long-term development - thus making it more challenging to enhance employee commitment - it did not seem to hamper the employees' internal motivation and drive. Uncertainty is often part and parcel of having an interesting and challenging occupation in various organisational environments. It also is possible that employees with a professional status and considerable experience have accepted the turbulence in the current working environments, got used to it, and found the means to adapt to the new situations. It might also be the case that employees today are more committed to their professional competence than to the organisation, and therefore have trust in their own market value (Heilmann, 2004). Therefore, they can bear some uncertainty relating to one aspect of job security as a hygiene factor (Herzberg, 1974), and they still may be able to find balance between knowledge sharing and protection.

However, the emphasis may vary slightly depending on the organisational functions involved. It seems that for people in R\&D who have internal motivation, commitment enhancing HR practices play an important role in terms of the success of HRM-based knowledge protection. In order to enhance commitment, the companies offered various opportunities for career advancement and also utilised rewards systems. Positive feedback and appraisal was recognised as important, but was not yet sufficiently common across all organisational levels (especially the operative level). The R\&D employees felt that practices for rewarding and giving feedback were too focused on tangible outcomes, leaving aspects like acknowledgement of handling knowledge appropriately aside. More attention should be paid to giving feedback on an ongoing basis. In fact, it seems that motivation was not seen just as a passive state - something beyond the sphere of influence of the company - but the interviewees had recognized some appropriate means to cultivate employee motivation. Most importantly it was an issue of empowering employees (see, e.g. Sels et al. 2006), allowing them 
enough freedom (see, e.g. Ahuja et al., 2013) - while at the same time educating them on knowledge protection informally - and selecting suitably challenging tasks (e.g. in terms of handling confidential information).

As an interesting and relevant factor, the sense of responsibility (see Matzler et al., 2011) seemed to be tightly coupled with trust-building practices. R\&D professionals feel strong loyalty towards their employer as long as they perceive their employer to be trustworthy. This could be a particular feature of the Finnish work ethic that seems to appear especially among personnel with several years of service history with the company. The focal role of immediate superiors and middle managers who present the face of the organisation, act as role models, and guide their subordinates to act in line with a sense of duty and obligation is also notable. Trust was seen to derive from mutual problem-solving and open communication in everyday work. Nevertheless, it was mainly the operative level personnel who stressed the importance of interpersonal and mutual trust, whereas for upper-level managers, role-based expectations on serving as an example and listening to employees seemed to be the primary concern. Open communication was emphasised across all organisational levels, but it may not be perceived in the same way at every level, which could also have an effect on how knowledge protection aspects are communicated and understood in different parts of the organization. This issue is also relevant because disturbances in this area may lead to increased (un)intentional knowledge leakages and staff turnover, both of which undermine knowledge protection endeavours.

One of the central findings in this study is that even if firms employ various practices to reduce the reliance on single actors, they are still dependent on their employees, and need to find ways to secure valuable resources that promote loyalty and ethical behaviour during and after employment relationships (see Liebeskind, 1996; 1997; Hannah and Robertson, 2014). These means are important, as they positively affect the retention of employees and through them, tacit knowledge. They also affect the diligence of the staff in safeguarding the confidentiality of company-critical intellectual assets. 


\section{Implications for theory and researchers}

Despite effort of few studies to capture the benefits of HRM -related mechanisms for knowledge leaking and leaving, the research on the use of them is still rather scarce. This study bridges the gaps that the authors have identified in the literature. This study contributes to theory in three main ways:

Firstly, the study contributes to current understanding by bridging the research on intellectual capital management and human resource management with the point of view of knowledge protection that is often neglected in both HRM and intellectual capital research while the interest is usually on issues such as job profitability and efficiency in generating intellectual capital.

Secondly, the study contributes to current literature by finding that the level of HRM-based knowledge protection is dependent on the employees' levels of loyalty that is built on 1) commitment (van den Hooff and de Ridder, 2004), 2) trust in the organisation (Brattström et al., 2012), 3) internal motivation (Mullins and Christy, 2013; Ahuja et al., 2013), and 4) sense of responsibility (see Matzler et al., 2011 on conscientiousness). This study identifies various practical tools can be employed to affect these factors. These are illustrated in Figure 1 below. While these aspects have been noted to be of importance for employees to be productive in conducting their work, this study has connected these issues to our knowledge as one of the first studies to knowledge protection and appropriation and addressed the related nuances, thereby contributing to current level of knowledge. 


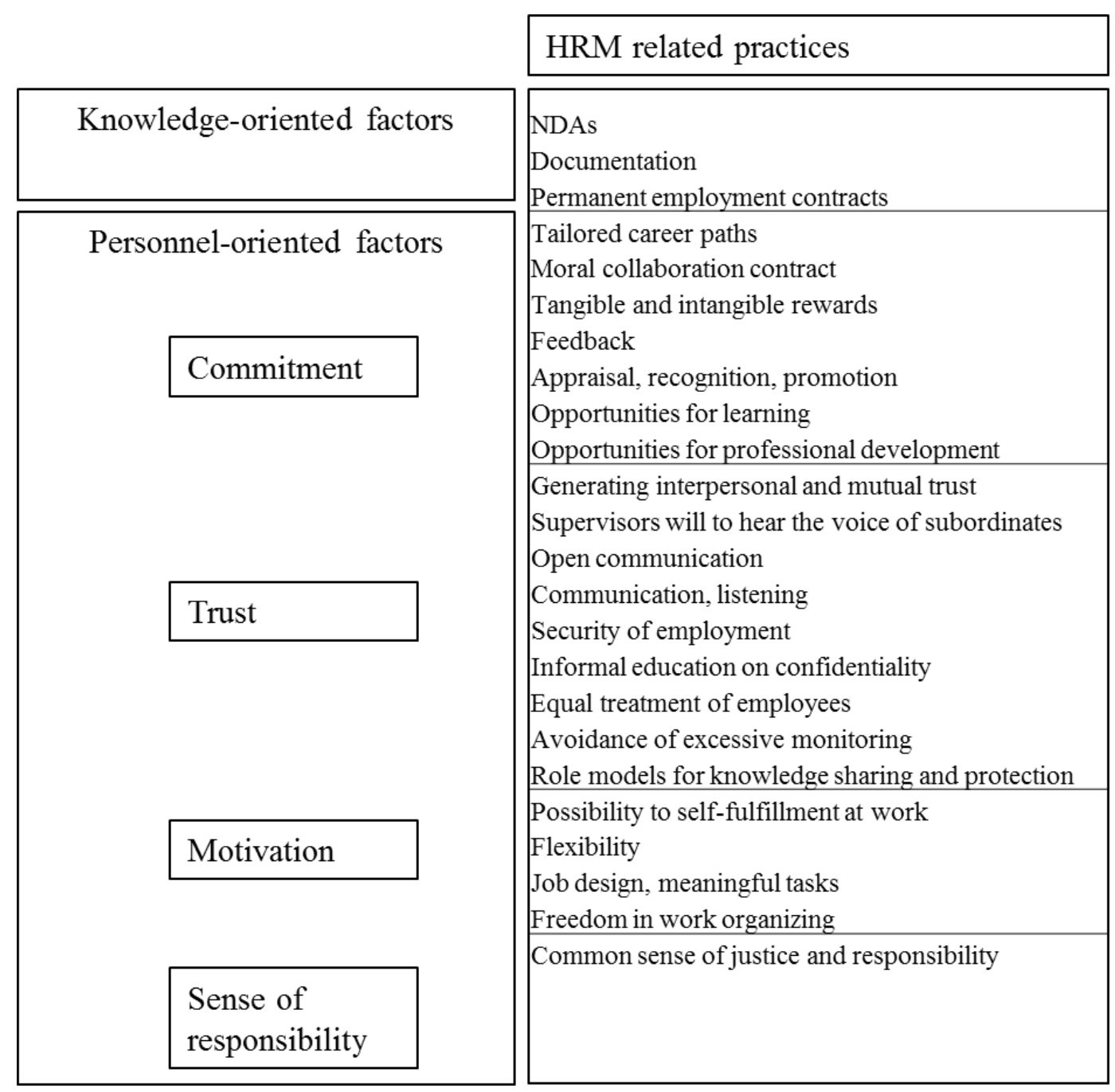

Figure 1 Human resource management-based mechanisms for diminishing knowledge leaving and leaking

Thirdly and finally, this study contributes to the literature on knowledge protection by HRM in large firms. While the focal role of employees in terms of sharing/protecting intellectual capital against leaking and leaving has been identified within large firms, it has not been researched as systematically as in SMEs, and seldom with qualitative in-depth data. Hence, this study has provided more understanding on the use of these mechanisms also in larger firms. The study reveals that while the issue of human resources in knowledge protection may be considered important for large companies, it may not always be managed consistently. Indeed, it seems that employees within R\&D intensive large firms are invaluable inventors, and not the weakest links, as long as they are being managed in the right way - especially considering the present day competitive situation. 


\section{Implications for practitioners}

Managers should note that the success of HRM-based knowledge protection depends on the levels of loyalty-increasing commitment, trust and the sense of responsibility, and also on the motivation perceived by employees - all of which can be affected through HRM-related practices. In particular, regular, honest and well-balanced feedback, meaning that both negative and positive aspects are brought up, is needed to drive internal motivation and interaction. Relatedly, while all aspects of decision-making cannot be totally open, at least the logic behind it could be made transparent, and the reasons for knowledge concealment made known to employees (see Hannah and Robertson, 2014): If the knowledge protection intent is communicated and executed poorly (consider, e.g., a situation where employees understand the purpose of education on confidentiality negatively because of inconsiderate communication by the management), the firm might plummet into a vicious cycle of using more control in order to prevent leaking, at the same time eroding trust and loyalty, which calls for even more control.

\section{Limitations}

The issues of knowledge protection and HRM practices were studied in a specific environment, which might affect the findings. Finnish culture, the national mindset, and the reputation issues prominent in a rather small country may play a role in terms of employee loyalty and knowledge leaving and leaking, likely making HRM-based practices more effective. These issues might appear differently in other countries where the legal system is different and/or where the business culture is more accepting to changing jobs in hope for a higher income, for example (see, e.g. O’Donoghue and Croasdell, 2009; Harcourt and Wood, 2007; Eger, 2004). 


\section{Further research}

In relation to the limitations noted in previous chapter, it would be relevant to study these issues in large firms in different market areas and across different cultures. In addition, while the qualitative approach taken in this study supports obtaining detailed views of the phenomenon in certain cases, to enable broader generalisation, it would be wise to examine other industries and more companies also quantitatively. In particular, here we have concentrated on examining how HR practices can contribute to protection of intellectual capital, but the reverse may apply also: the two-directional relationship between HRM enhancing loyalty and knowledge protection practices warrants research. This study indicates the type of tools needed to continue the examination of these aspects.

\section{References}

Aaron, B. and Finkin, M. (1998). 'The Law of Employee Loyalty in the United States' Comparative Labor Law \& Policy Journal, 20, 321.

Agarwal, R., Ganco, M. and Ziedonis, R. H. (2009). 'Reputations for toughness in patent enforcement: implications for knowledge spillovers via inventor mobility' Strategic Management Journal, 30, 1349-1374.

Ahuja, G., Lampert, C.M. and Novelli, E. (2013). 'The second face of appropriability: generative appropriability and its determinants' Academy of Management Review, 38: 2, 248-269.

Allen, N. and Meyer J. (1990). 'The measurement and antecedents of affective, continuance and normative commitment to organization' Journal of Occupational Psychology, 63, 1, 1-18.

Allen, N. and Meyer, J. (1997). Commitment on the Workplace - Theory, Research, Application. Thousand Oaks: Sage Publications.

Argyris, C. (1960). Understanding Organisational Behaviour. Homewood, Illinois: Dorsey Press.

Arnold, J. (1997). Managing Careers into the 21st century. London: Sage Publications. 
Barney, J. (1991). 'Firm resources and sustained competitive advantage' Journal of Management, 17: $1,99-120$.

Baughn, C.C., Stevens, J.H., Denekamp, J.G. and Osborn, R.N. (1997). 'Protecting intellectual capital in international alliances' Journal of World Business, 32: 2, 103-117.

Bontis, N. and Fitz-Enz, J. (2002). 'Intellectual capital ROI: a causal map of human capital antecedents and consequents' Journal of Intellectual Capital, 3: 3, 223-247.

Boxall, P. (1998). 'Achieving competitive advantage through human resource strategy: Towards a theory of industry dynamics' Human Resource Management Review, 8: 3, 265-288.

Brattström, A., Löfsten, H. and Richtnér, A. (2012) 'Creativity, trust and systematic processes in product development' Research Policy, 41, 743- 755.

Camelo-Ordaz, C., Garcia-Cruz, J., Sousa-Ginel, E. and Valle-Cabrera, R. (2011) 'The influence of human resource management on knowledge sharing and innovation in Spain: the mediating role of affective commitment' International Journal of Human Resource Management, 22: 7, 1442-1463.

Chesbrough, H. (2003) 'The Logic of Open Innovation: Managing Intellectual Property’ California Management Review, 45: 3, 33-58.

Cohen, W.M., Nelson, R.R. and Walsh, J.P. (2000). 'Protecting their intellectual assets: Appropriability conditions and why US manufacturing firms patent (or not)' NBER Working paper 7552.

Currie, G. and Kerrin, M. (2003). 'Human resource management and knowledge management: enhancing knowledge sharing in a pharmaceutical company' International Journal of Human Resource Management, 14: 6, 1027-45.

Davis, L. (2004). 'Intellectual property rights, strategy and policy' Economics of Innovation and New Technology, 13: 5, 399-415.

Dessler, G. (2008). Human Resource Management. $11^{\text {th }}$ ed. Pearson, Prentice Hall.

Droeger, S. B. and Hoobler, J.M. (2003). 'Employee Turnover And Tacit Knowledge Diffusion: A Network Perspective' Journal of Managerial Issues, 15: 1, 50-64. 
Eger, T. (2004). 'Opportunistic termination of employment contracts and legal protection against dismissal in Germany and the USA' International Review of Law and Economics, 23, 381-403.

Eisenhardt, K.M. and Graebner, M.E. (2007). 'Theory building from cases: opportunities and challenges' Academy of Management Journal, 50: 1, 25-32.

Fiorito, J., Bozeman, D., Young, A. and Meurs, J. (2007). 'Organizational Commitment, Human Resource Practices, and Organizational Characteristics' Journal of Managerial Issues. 19: 2, 186-207.

Haesli, A. and Boxall, P. (2005). 'When knowledge management meets HR strategy: an exploration of personalization-retention and codification-recruitment configurations' International Journal of Human Resource Management, 16: 11, 1955-75.

Hannah, D.R. (2005). 'Should I keep a secret? The effects of trade secret protection procedures on employees' obligations to protect trade secrets' Organization Science, 16: 1, 71-84.

Hannah, D.R. and Robertson, K. (2014). 'Why and how do employees break and bend confidential information protection rules?' Journal of Management Studies (in Press).

Harabi, N. (1995). 'Appropriability of technical innovations. An empirical analysis' Research Policy, 24, 981-992.

Harcourt, M. and Wood, G. (2007). 'The importance of employment protection for skill development in coordinated market economies' European Journal of Industrial Relations, 13: 2, 141-159.

Heilmann, P. (2004). Careers of Managers, Comparison between ICT and Paper Business Sectors. Acta Universitatis Lappeenrantaensis, 195, (Diss.) Lappeenranta University of Technology, Digipaino.

Heilmann P. (2010). 'To have and to hold - Personnel shortage in a Finnish health care organization' Scandinavian Journal of Public Health, 2010; 38: 518-523.

Herriot, P. (1992). The Career Management Challenge. Balancing Individual and Organizational Needs. London: Sage Publications. 
Herzberg, F. (1974). 'Motivation-hygiene profiles. Pinpointing what ails the organization' Organizational Dynamics, 3: 2, 18-29.

Hertzfeld, H.R., Link, A.N. and Vonortas, N.S. (2006). 'Intellectual property protection mechanisms in research partnerships' Research Policy, 35, 825-838.

Huczynski, A. and Buchanan, D. (2007). Organizational Behaviour, sixth ed. London: Prentice Hall.

Hurmelinna-Laukkanen, P. and Gomes, J.F.S. (2012) 'HRM system strength - HRM harnessed for innovation, appropriability and firm performance' Economics and Business Letters, 4: 1, 43-53.

Hurmelinna-Laukkanen, P. and Puumalainen, K. (2007). 'Nature and dynamics of appropriability: Strategies for appropriating returns on innovation' $R \& D$ Management, 37: 2, 95-110.

Innocenti, L., Pilati, M. and Peluso, A.M. (2011). 'Trust as a moderator in the relationship between HRM practices and employee attitudes' Human Resource Management Journal, 21: 3, 303-317.

James, S.D., Leiblein, M.J., and Lu, S. (2013). 'How firms capture value from their innovations' Journal of Management, 39: 5, 1123-1155.

Janssens, M., Sels, L. and Van den Brande, I. (2003). 'Multiple Types of Psychological Contracts: A Six-Cluster Solution’ Human Relations, 56: 11, 1349-1378.

John, O.P., and Srivastava, S. (1999), 'The Big Five Trait Taxonomy: History, Measurement and Theoretical Perspectives,' in Handbook of Personality, eds. L.A. Pervin and O.P. John, New York, NY: Guilford Press, pp. 102-138.

Kianto, A., Hurmelinna-Laukkanen, P. and Ritala, P. (2010). 'Intellectual capital in service- and product-oriented companies' Journal of Intellectual Capital, 11: 3, 305-325.

Kinnie, N. and Swart, J. (2012) 'Committed to whom? Professional knowledge worker commitment in cross-boundary organisations' Human Resource Management Journal, 22: 1, 21-38.

Klein Woolthuis, R., Bas, H. and Nooteboom, B. (2005). 'Trust, contract and relationship development' Organization Studies, 26: 6, 813-840. 
Lang, J.C. (2001). 'Management of intellectual property rights - Strategic patenting' Journal of Intellectual Capital, 2: 1, 8-26.

Lawler, E.E. III (2003). Treat People Right!: How Organizations and Individuals Can Propel Each Other into a Virtuous Spiral of Success. San Francisco: Jossey-Bass.

Leiponen, A. and Byma, J. (2009). 'If you cannot block, you better run: Small firms, cooperative innovation, and appropriation strategies' Research Policy, 38, 1478-88.

Liebeskind, J.P. (1996). 'Knowledge, strategy, and the theory of the firm' Strategic Management Journal, 17, 93-107.

Liebeskind, J.P. (1997). 'Keeping organizational secrets: Protective institutional mechanisms and their costs' Industrial and Corporate Change, 6: 3, 623-663.

Maslow, A. (1954). Motivation and personality. New York: Harper \& Row.

Massingham, P. R., and Tam, L. (2015). 'The relationship between human capital, value creation and employee reward' Journal of Intellectual Capital, 16: 2.

Matzler, K., Renzl, B., Mooradian, T., von Krogh, T., Mueller, J., (2011). 'Personality traits, affective commitment, documentation of knowledge, and knowledge sharing' The International Journal of Human Resource Management, 22: 2, 296-310.

McDonough, E. F. (2000). 'Investigation of Factors Contributing to the Success of Cross-Functional Teams' Journal of Product Innovation Management, 17: 3, 221-235.

McEvily, S.K. and Chakravarthy, B. (2002). 'The persistence of knowledge-based advantage: An empirical test for product performance and technological knowledge' Strategic Management Journal, 23, 285-305.

Meyer, J.P., Allen N.J. and Smith C.A. (1993). 'Commitment to organizations and occupations: Extension and test of a three-component conceptualization' Journal of Applied Psychology, 78: 4, 538-551.

Mir, A., Mir, R. and Mosca, J.B. (2002). 'The new age employee: An exploration of changing employee-organization relations' Public Personnel Management. 31, 187-200. 
Mohamed, S., Mynors, D., Grantham, A., Chan, P., Coles, R., Walsh, K. (2007). 'Unearthing key drivers of knowledge leakage' International Journal of Knowledge Management Studies, 1: 3-4, 456470.

Mowday, R.T., Steers, R.M. and Porter, L.W. (1979). 'The measurement of organizational commitment' Journal of Vocational Behavior, 14, 223-247.

Mowday, R., Porter, L. and Steers, S. (1982). Employee-Organization Linkages. New York: Academic Press.

Mullins, J. and Christy, G. (2013). Management \& Organisational Behaviour, $10^{\text {th }}$ ed. London: Pearson.

Nonaka, I. and Takeuchi, H. (1995). The Knowledge-Creating Company. New York: Oxford University Press.

Nonaka, I., Toyama, R. and Konno, N. (2000). 'SECI, Ba and Leadership: a Unified Model of Dynamic Knowledge Creation’ Long Range Planning, 33: 1, 5-34.

Norman, P.M (2001). 'Are your secrets safe? Knowledge protection in strategic alliances' Business Horizons, 44: 6, 51-60.

O'Donoghue, N. and Croasdell, D.T. (2009). 'Protecting knowledge assets in multinational enterprises: a comparative case approach', VINE, 39: 4, 298 - 318.

Olander, H., Hurmelinna-Laukkanen, P. and Mähönen, J. (2009). 'What's small size got to do with it - Protection of intellectual assets in SMEs' International Journal of Innovation Management, 13: 3, 349-370.

Olander, H., Hurmelinna-Laukkanen, P. and Heilmann, P. (2011). 'Do SMEs benefit from HRMrelated knowledge protection in innovation management?' International Journal of Innovation Management, 15: 3, 593-616.

Oltra, V. (2005). 'Knowledge management effectiveness factors: the role of HRM'. Journal of Knowledge Management, 9: 4, 70-86. 
Redman, T. and Wilkinson A. (2009). Contemporary Human Resource Management. Text and Cases. 3rd ed. Prentice Hall.

Reichers, A. (1985). 'A review and reconceptualization of organizational commitment' Academy of Management Review, 10, 465-476.

Riahi-Belkaoui, A. (2003) 'Intellectual capital and firm performance of US multinational firms: a study of the resource-based and stakeholder views' Journal of Intellectual capital, 4: 2, 215-226.

Rousseau, D. (2011). 'The individual-organization relationship: the psychological contract', in S Zedeck (ed), APA Handbook of Industrial and Organizational Psychology, 3, 191-220, Washington, DC: American Psychological Association.

Rousseau, D. (1995). Psychological Contracts in Organizations: Understanding Written and Unwritten Agreements, Thousand Oaks, CA: Sage Publications.

Rousseau, D. and Schalk, R. (2000). Psychological Contracts in Employment. Cross-National Perspectives, Thousand Oaks, CA: Sage Publications.

Rousseau, D. and Wade-Benzoni, K. (1995). 'Changing individual-Organizational attachments', in A Howard (ed), The Changing Nature of Work, 290-322, San Francisco, CA: Jossey-Bass.

Schalk, R. and Rousseau, D. (2001). 'Psychological contracts in employment', in N Anderson, D Ones, H Kepir Sinangil and C Viswesvaran (eds), Handbook of Industrial, Work and Organizational Psychology, 133-142, Thousand Oaks, CA: Sage Publications.

Sels, L, De Winne, S., Maes, J., Delmotte, J., Faems, D. and Forrier, A. (2006). 'Unravelling the HRM-performance link: Value-creating and cost-increasing effects of small business HRM' Journal of Management Studies, 43: 2, 319-342.

Storey, J. and Quintas, P. (2001). 'Knowledge management and HRM', in J. Storey (ed), Human Resource Management: A critical text, 339-363, London: Thomson Learning.

Ståhle, P. and Grönroos, M. (1999). Knowledge Management - tietopääoma yrityksen kilpailutekijänä. Porvoo, Finland: WSOY. 
Teece, D.J. (1986). 'Profiting from technological innovation: Implication for integration, collaboration, licensing and public policy' Research Policy, 15: 6, 285-305.

Torrington, D., Hall L., Taylor S. and Atkinson C. (2011). Human Resource Management. $8^{\text {th }}$ ed. Prentice Hall.

Truss, C., Mankin D. and Kelliher C. (2012). Strategic Human Resource Management. Oxford University Press.

Van den Hooff, B. and de Ridder, J.A. (2004) 'Knowledge sharing in context: the influence of organizational commitment, communication climate and CMC use on knowledge sharing' Journal of Knowledge Management, 8: 6, 117-130.

Vroom, V. (1964). Work and motivation. New York: Wiley.

Zander, U. and Kogut, B. (1995). 'Knowledge and the speed of transfer and imitation of organizational capabilities: an empirical test' Organization Science, 6, 76-92. 